Dückers, M.L.A., Yzermans, C.J., Jong, W., Boin, A. Psychosocial crisis management: the unexplored intersection of crisis leadership and psychosocial support. Risk, Hazards \& Crisis in Public Policy: 2017, 8(2), 94-112

\begin{tabular}{|l|l|}
\hline $\begin{array}{l}\text { Postprint } \\
\text { Version }\end{array}$ & 1.0 \\
\hline Journal website & http://onlinelibrary.wiley.com/doi/10.1002/rhc3.12113/abstract \\
\hline Pubmed link & \\
\hline DOI & $10.1002 /$ rhc3.12113 \\
\hline
\end{tabular}

This is a NIVEL certified Post Print, more info at http://www.nivel.eu

\title{
Psychosocial Crisis Management: The Unexplored Intersection of Crisis Leadership and Psychosocial Support
}

\author{
Michel L. A. DÜCKERS, C. JORIS YZERMANS, WOUTER JONG, ARJEN BOIN
}

Michel L. A. Dückers is program coordinator at Impact-National Knowledge and Advice Centre for Psychosocial Care Concerning Critical Incidents, 1112 XE Diemen, The Netherlands and senior researcher at NIVEL-Netherlands Institute of Health Services Research, Otterstraat 118-124, 3513 CR Utrecht, The Netherlands [ m.duckers@nivel.nl].

C. Joris Yzermans is senior researcher at NIVEL-Netherlands Institute of Health Services Research, Otterstraat 118-124, 3513 CR Utrecht, The Netherlands.

Wouter Jong is researcher at INTERVICT, Tilburg University, PO Box 90153, 5000 LE Tilburg, The Netherlands and crisis consultant at the Dutch Association of Mayors (Nederlands Genootschap van Burgemeesters), Nassaulaan 12, 2514 JS, The Hague, The Netherlands.

Arjen Boin is Professor of Public Institutions and Governance at the Institute of Political Science, Leiden University, 2333 AK Leiden, The Netherlands.

\begin{abstract}
Epidemiological research has documented the serious health issues that can affect the victims of disasters and major crises. Yet, the psychosocial dimension of crisis has received little attention in crisis management literature. This paper integrates psychosocial principles with a model of strategic crisis management. The resulting model of psychosocial crisis management (PCM) describes how the tasks of strategic crisis managers can be guided by psychosocial support principles. This PCM-model helps public leaders, at society and local community level, to better understand typical psychosocial dynamics and obstacles as the crisis life cycle evolves. Although crisis management insights and psychosocial support principles stem from different disciplines and research traditions, integrating them helps to reduce foreseeable problems in the response and recovery phases.
\end{abstract}

\section{INTRODUCTION: THE FORgOTTEN DIMENSION OF CRISIS MANAGEMENT}

Communities everywhere can be confronted with crises and disasters, events that disturb the normal order of everyday life. A crisis often entails undesirable circumstances, which are characterized by a widely perceived threat to core values, 
Dückers, M.L.A., Yzermans, C.J., Jong, W., Boin, A. Psychosocial crisis management: the unexplored intersection of crisis leadership and psychosocial support. Risk, Hazards \& Crisis in Public Policy: 2017, 8(2), 94-112

deep uncertainty, and time pressure (Boin, 't Hart, Stern, \& Sundelius, 2016; Brecher, 1993; Rosenthal, Charles, \& 't Hart, 1989; Rosenthal, Boin, \& Comfort, 2001; Stern $\&$ Sundelius, 2002). We define crisis management as the set of efforts aimed to deal with the consequences of crises, "before, during and after they have occurred" (Shrivastava, Mitroff, Miller, \& Miglani, 1988, p. 287; also see Boin et al., 2016). Crises can have substantial consequences for the well-being, functioning, and health of those affected by them (this also applies to complex emergencies in conflict areas; Salama et al., 2004). Typical effects include stress, fear, uncertainty, physical symptoms, and trauma-related mental health problems. Disaster health effects have been studied extensively, and in recent decades with an emphasis on mental health and post-traumatic stress disorder (PTSD) (e.g., Bonanno, Brewin, Kaniasty, \& La Greca, 2010; Bonde et al., 2016; Galea, Nandi, \& Vlahov, 2005; Herbert et al., 2006; Moline, Herbert, \& Nguyen, 2006; Norris et al., 2002; Yzermans, Van Der Berg, \& Dirkzwager, 2009).

Although such effects yield psychological dynamics and influence social interactions within affected communities (Dückers, 2017), and thus demand a response from public leaders, the psychosocial dimension of crises has received little attention in crisis management literature. The aim of this paper, therefore, is to integrate psychosocial principles, relevant to anticipating the well-being, functioning, and health of people confronted with potentially impactful events, into crisis leadership theory. We focus on public leaders and crisis managers at national or local level: public officials at the strategic apex of public organizations with a formal responsibility to manage the disaster response and recovery network. In the context of crisis management, these leaders will have to deal with a set of strategic crisis management challenges and tasks. After briefly discussing the crisis leadership tasks, we explore the degree of integration between the tasks and psychosocial support principles as described in the literature. As a final step, we present a model of effective psychosocial crisis management (PCM).

\section{Strategic Crisis MANagement Challenges AND TASKS}

The challenges of strategic crisis management are daunting (for detailed overviews see Boin et al., 2016; Boin \& 't Hart, 2011). To overcome these challenges, strategic crisis managers must focus on a set of tasks (Boin et al., 2016). Research suggests that the effective organization and implementation of these tasks helps strategic crisis managers to impose order in the network that is charged with responding to disaster. The following six tasks are distinguished: The sense-making task requires crisis managers to diagnose unfolding crisis situations adequately, often making use of scarce and ambiguous information. The core of the decision-making task is to identify critical decisions that can and should only be made at strategic level. The coordination task refers to the alignment of key actors in a response network, during and after the crisis (Boin \& Bynander, 2015; Dückers, Rooze, \& Alexander, 2014; Heller, 2010). Coordination is about allocating capacity and limited resources to facilitate the cooperation between particular organizations and groups. Meaning making is about providing a convincing narrative, an explanation of a crisis and its causes, its implications, the response, and the envisioned roles of different actors. Account giving refers to the democratic duty to clarify and accept responsibilities, without engaging in scapegoating. Learning requires crisis management actors to critically assess their own functioning and to draw lessons from it to enhance their 
Dückers, M.L.A., Yzermans, C.J., Jong, W., Boin, A. Psychosocial crisis management: the unexplored intersection of crisis leadership and psychosocial support. Risk, Hazards \& Crisis in Public Policy: 2017, 8(2), 94-112

future performance, both during and after a crisis (Alexander, 2012; Smith \& Elliott, 2007; Stern, 1997).

\section{EXPLORATORY LITERATURE REVIEW}

To get an impression of how PCM has been discussed in recent literature, we carried out an electronic search in Medline, PsycINFO, Cochrane, ProQuest (combined search of PILOTS and Sociological Abstracts), and Web of Science. These databases contain publications from broad fields such as sociology, psychology, public health, political science, and public management. The search was conducted on May 20 2016 using the following string of search terms: (psychosocial OR "psycho-social" OR psychologic*) AND ("crisis management" OR "disaster management" OR "emergency management" OR "crisis leadership"). We did not use a date restriction and selected relevant publications written in English, German, and Dutch based on an assessment of titles and abstracts. After removing duplicates, our search resulted in 436 publications, which we then reviewed. As our interest is primarily restricted to public crises and disasters, we excluded studies about the workplace, corporate crises, medical crisis interventions, suicide, and health disorders. We mostly found guidelines, discussion papers, and reflections, presenting primarily qualitative findings, which meant the material did not allow for formal meta-analysis. Our literature study shows that crisis leadership and psychosocial support generally form two distinctive streams with limited unification or integration, despite their evidently shared area of interest. The study of crisis management is only moderately concerned with the psychosocial dimension of crises. Studies of crisis-related psychosocial support focus more on the impact on affected individuals-particularly the development of trauma-related mental health problems - than on crisis management dilemmas and problems. Numerous publications are devoted to particular models, interventions, or approaches that are suggested to be helpful in addressing trauma-related problems in individuals and groups (e.g., Clark \& Volmann, 2005; Everly, 2000; Hammond \& Brooks, 2002; Mitchell \& Everly, 2006). However, because of a lack of evidence contemporary international evidencebased guidelines do not recommend early preventive measures that go further than the strengthening of social support, provision of information, and timely detection of serious health problems (Australian Centre for Posttraumatic Mental Health [ACPMH], 2013; Bisson et al., 2010; Juen et al., 2015; Te Brake \& Dückers, 2013; World Health Organization [WHO], 2013).

The studies differ in their timeframe orientation. Several authors focus on the early phase of the crisis (Burkle, 1996; Van Loon, 2008), others take a longer term view (Buckle, Brown \& Dickinson, 1998; Weaver, 1995). The few publications that explicitly speak of PCM use it as a synonym for psychosocial support in crisis situations (e.g., Beerlage \& Helmerichs, 2011; Bering, Elklit, Schedlich, \& Zurek, 2009; Hannig \& Harks, 2009; Uhle \& Haubner, 2005). Van Loon (2008) views PCM as "primarily aimed at 'normalizing' and gaining control over more or less increased levels of commotion during and after a calamity" (p. 115).

We found many topics that are relevant from a PCM-perspective, but we did not find an integrated model combining principles from crisis leadership and psychosocial support. Before we can produce such a model, we first need to describe the main building blocks. The crisis management tasks grounded in the work by Boin and ' $t$ Hart have already been discussed. In the next section, we integrate the findings from 
Dückers, M.L.A., Yzermans, C.J., Jong, W., Boin, A. Psychosocial crisis management: the unexplored intersection of crisis leadership and psychosocial support. Risk, Hazards \& Crisis in Public Policy: 2017, 8(2), 94-112

the exploratory review into an overview of psychosocial support principles. Subsequently, we make a synthesis between the principles and the set of general crisis management tasks.

\section{PRINCIPLES OF PSYCHOSOCIAL SUPPORT}

The literature describes a variety of psychosocial support principles. We clustered them into three categories:

- consideration of needs, problems, risks, and existing capacities;

- provide a supportive context;

- evaluate and implement lessons.

\section{Consideration of Needs, Problems, Risks, and Existing Capacities}

\section{Assess Needs and Problems}

The needs and problems of affected populations, which response and recovery planners should consider, can cover a variety of issues such as: shelter, safety, food, drinking water, first aid, and medication (basic aid); information about what has happened, about the fate of loved ones, and about possible stress reactions (information); comfort, a listening ear, recognition of grief, compassion (social and emotional support); legal and financial problems, establishing a household again (practical help); and mental and physical health problems (health care) (Dückers \& Thormar, 2015). The psychosocial needs and problems of people affected by disasters tend to change over time. These changes in psychosocial needs are related to the deterioration of social support (Amaratunga, 2006; see "consider risk and protective factors"). Rao (2006) states that support efforts should be "modulated according to the phase of recovery following the event occurrence because each phase will highlight different needs. (...). In the initial phases, the emphasis is placed on social intervention that can be delivered by community-level workers. In the later phases, the psychological issues that emerge necessitate the services of trained professionals" (p. 501).

The large range of problems mentioned demonstrates the need for flexibility and improvisation skills among psychosocial care providers (Van Loon, 2008). Stress is considered a normal reaction after a potentially shocking event. According to Van Loon (2008), psychosocial care providers involved in the provision of immediate psychosocial help to affected people, should not (only) focus on the possible development of event-related mental health problems (like PTSD) among victims. Putting emphasis on the treatment of psychological problems is considered too narrow given the extent of the needs and problems associated with the psychosocial well-being of affected people (Van der Velden, Van Loon, Kleber, Van Uhlenbroek, \& Smit, 2009).

\section{Consider Risk and Protective Factors}

Effective psychosocial support requires an understanding of who is at risk within an affected population (e.g., vulnerable groups such as people displaced, children, and the elderly, but also first responders and other helpers). Typical risk factors linked to the prevalence of mental health complaints and a limited capacity for self-recovery should guide psychosocial support. Studies refer to risk factors such as lower socio- 
Dückers, M.L.A., Yzermans, C.J., Jong, W., Boin, A. Psychosocial crisis management: the unexplored intersection of crisis leadership and psychosocial support. Risk, Hazards \& Crisis in Public Policy: 2017, 8(2), 94-112

economic status, female gender, lack of social support, exposure to death and loss, and existing mental health problems (Bonanno et al., 2010; Brewin, Andrews, \& Valentine, 2000; Ozer, Best, Lipsey, \& Weiss, 2003). Additional stress is caused by actual or potential "resource loss," the loss of anything that matters to a person (Hobfoll, 1998), for instance, in terms of relations, possessions, work, someone's role in society and status. A risk reduction approach should incorporate addressing additional sources of stress linked to resource loss and other stress factors (Van der Velden et al., 2009).

Social support is a key component of community resilience (Norris, Stevens, Pfefferbaum, Wyche, \& Pfefferbaum, 2008) and - if absent - a well-known risk factor for the development of trauma-related mental health problems and, possibly, the attribution of physical symptoms from experiencing the event. Social support can vary if a person's life circumstances change, for instance, if someone moves to a new location, or if circumstances are altered by the disaster itself. Levels of social support, as perceived by affected citizens, tend to deteriorate in a disaster's aftermath (Kaniasty \& Norris, 2004; Kaniasty, Norris, \& Murrell, 1990). Collective emergencies can dramatically impact interpersonal social dynamics and the availability of community resources (Bonanno et al., 2010). The disaster stages model (Raphael, 1986; Yzermans \& Gersons, 2002) illustrates the psychosocial impact of crises as an "emotional timeline." The "impact" phase is followed by a "honeymoon" phase with extensive levels of social support (sympathy, compassion, and attention from family members, friends, coworkers, community actors, governments, and media). In the "disillusionment" phase, in the weeks or months after a crisis, social support diminishes as the survivors and the bereaved pick up the thread of normal life. Raphael (1986) speaks of a "second disaster" when individual and community adaptive capacities reach a minimum. Gradually, the amount of social support is expected to regrow, with likely fall-backs, as an affected person overcomes the impact and enters a phase of "reintegration."

\section{Strengthen and Utilize Existing Capacities}

A core principle in the psychosocial support literature in disaster settings refers to strengthening and utilizing resilience, that is, adaptation or recovery capacity and resources available to individuals, communities, and societies (Bonanno et al., 2010; Dückers, 2017; Norris et al., 2008). Well before the current popularity of resilience theory in disaster mental health research, Omer and Alon (1994) noted that "the continuity principle stipulates that through all stages of disaster, management and treatment should aim at preserving and restoring functional, historical, and interpersonal continuities" at the level of "individual, family, organization, and community" (p. 273). The dominant perspective in the international literature is that the vast majority of people confronted with a potentially shocking event are capable of dealing with the psychological impact and capable of self-recovery (Bonanno et al., 2010). Some individuals will develop problems they cannot overcome themselves. While some authors focus on the capacity to adapt and interventions at individual level, others stress the importance of community-level resources/capacities, interventions, and programs (Basu et al., 2013; Comfort, Siciliano, \& Okada, 2011; Dudley-Grant, Mendez, \& Zinn, 2000; Dückers, 2017; Kapucu, Hawkins, \& Rivera, 2013; Norris et al., 2006, 2008; Vernberg, 2002; Vymetal, 2006). 
Dückers, M.L.A., Yzermans, C.J., Jong, W., Boin, A. Psychosocial crisis management: the unexplored intersection of crisis leadership and psychosocial support. Risk, Hazards \& Crisis in Public Policy: 2017, 8(2), 94-112

\section{Provide a Supportive Context}

Experts agree upon the importance of providing affected people with a "supportive context," which may include offering a listening ear, support and comfort, and being sensitive to immediate practical needs; offering practical and up-to-date information about the event; mobilizing support from one's own social environment; facilitating reunions with family and keeping them together; and reassuring people who are displaying stress reactions that their reactions are normal (Te Brake \& Dückers, 2013). The notion of such a supportive context — which can be realized nationally or locally by government, businesses, and civil society actors - is reflected in three psychosocial principles:

- provision of information and basic aid;

- promote a sense of safety, calmness, self- and community efficacy, connectedness to others, and hope;

- social acknowledgment.

\section{Provision of Information and Basic Aid}

Information about the crisis, causes, and consequences, especially those killed, missing, or relocated, but also information on the status of response and recovery processes, practical guidance, and possible health reactions, is highly valuable for people confronted by a disaster. The same applies to direct basic needs such as safety, emergency first aid, shelter, water, and food, and reunification with loved ones, friends, and family members (Bisson et al., 2010; Te Brake \& Dückers, 2013).

Promote a Sense of Safety, Calmness, Self- and Community Efficacy, Connectedness to Others, and Hope

Hobfoll et al. (2007) identified five essential psychosocial support principles, relevant for anyone who interacts with people exposed to crises. It is necessary to promote a sense of safety, calmness, self- and community efficacy, connectedness to others, and hope.

\section{Social Acknowledgment}

Maercker and Müller (2004) defined social acknowledgment as "a victim's experience of positive reactions from society that show appreciation for the victim's unique state and acknowledge the victim's current difficult situation. The term social here not only includes the (...) victim's [closest social network] (e.g., family, friends), but also significant persons (e.g., local authorities, clergy), groups (e.g., at the workplace, fellow citizens), and impersonal expression of opinions (e.g., media) about the experiences of the victims or survivors" (p. 345). Social acknowledgment is low if people affected experience societal disapproval, misunderstanding, criticism, rejection, or a lack of support. This can be problematic because it is social support that they are seeking.

\section{Evaluate and Implement Lessons}

The psychosocial support principles described above under "consideration of needs, problems, risks, and existing capacities" and "provide a supportive context" can be seen as assignments for the many different actors that are involved in the different stages of planning and the delivery of services to affected individuals and communities. In the principles under the third category, they can contribute to 
Dückers, M.L.A., Yzermans, C.J., Jong, W., Boin, A. Psychosocial crisis management: the unexplored intersection of crisis leadership and psychosocial support. Risk, Hazards \& Crisis in Public Policy: 2017, 8(2), 94-112

closing the learning loop and service optimization. From a quality improvement perspective, the challenge is to approach each unique disaster context with the same series of quality improvement steps (plan-do-study-act) and to integrate (mental) health research into post-disaster management planning (Dückers \& Thormar, 2015; Greenberg, Rubin, \& Wessely, 2009; Reifels et al., 2013). First, collect information, rigorously and rapidly, about the needs, problems, risks, and (a lack of) adaptive capacities of the people exposed, also to verify whether expectations and assumptions are correct. Ideally, the psychosocial needs of the public, first response team, support staff, and volunteers will be assessed before advancing to the next stage of the disaster timeline (Amaratunga, 2006). Second, prioritize the issues that must be addressed and design a practical approach with clear roles and tasks for the actors involved, as well as required conditions ("plan"). Third, carry out the activities as planned ("do"). Fourth, evaluate the result in relation to the original plan and check whether principles are being put into practice ("study"). The final step, closing the loop, is to adjust the plan if necessary, to proceed with the plan or to end it ("act"). These steps increase the chance that affected populations will be served in an effective, efficient, need-centered, safe, and appropriate way (Dückers \& Thormar, 2015). Basic "quality" criteria like these can be used to evaluate psychosocial support (including the performance of distinctive partners or networks) in positive or negative terms and, when appropriate, to implement lessons to improve the support of affected people in the present and the future.

\section{Psychosocial Crisis Management: A Conceptual Model}

\section{Bringing Crisis Leadership Challenges and Psychosocial Support Together}

The next step is to bring crisis leadership and psychosocial support principles together in one PCM-model. The strategic crisis management model is thus enriched with insights from psychosocial literature. The six leadership tasks are used as the main platform for the development of a PCM-model to better understand typical challenges related to the psychosocial dimension of crises. In Figure 1 the crisis leadership challenges and psychosocial support principles are shown in different rings, linked to each other and centered around the well-being, functioning, and health of citizens exposed to potentially traumatic events. While psychosocial support principles are particularly relevant to professionals and trained volunteers, from a PCM-perspective they also provide meaningful guidance to public leaders with a responsibility for the well-being, functioning and health of citizens at national or local community level. Crisis leadership tasks and psychosocial support principles are structured anti-clockwise along the stages in the plan-do-study-act cycle in Figure 1.

\section{[FIGURE 1.]}

\section{Sense Making}

From a psychosocial perspective, sense making is needed to make an assessment of the event and its potential effects on the exposed population. This assessment should identify psychosocial risks, needs and problems, risk factors (insufficient) capacity to adapt, preferably guided by lessons learned from earlier situations. In the early phase of a crisis, the PCM-response is hindered by a lack of information. Public leaders have to access different channels to obtain necessary information. At individual level 
Dückers, M.L.A., Yzermans, C.J., Jong, W., Boin, A. Psychosocial crisis management: the unexplored intersection of crisis leadership and psychosocial support. Risk, Hazards \& Crisis in Public Policy: 2017, 8(2), 94-112

this can be done based on informal conversations with the affected (Jong, Dückers, \& Van der Velden, 2016a), or more formally through an investigation or professional diagnosis. At community or country level it is possible to perform a rapid health and needs assessment (Korteweg, Van Bokhoven, Yzermans, \& Grievink, 2010), a health monitor to follow the development in time of mental and physical health (Yzermans et al., 2009; Yzermans, Baliatsas, Van Dulmen, \& Van Kamp, 2016), or an analysis of social media, newspaper, or television broadcasting to understand emotions and perceived PCM-outcomes within local communities (Back, Küfner, \& Egloff, 2010; Griffin-Padgett \& Allison, 2010; Jong \& Dückers, 2016; Jong et al., 2016a). Although these activities are helpful there is always a risk that sense making intensifies the crisis (Weick, 1988). Asking people about possible health consequences, may make them believe they are suffering or are going to suffer from a physical ailment and therefore make them extra aware of symptoms, regardless of whether these symptoms are linked to exposure.

\section{Decision Making}

Crisis leaders must make critical choices, also in relation to the psychosocial impact and necessary aftercare in the short-term as well as in the long-term. To ensure that the right principles are reflected in strategic crisis decision making, crisis leaders must be informed about particular characteristics and challenges surrounding the psychosocial dimension of crises, including the lessons learned from earlier disasters and major events (see "learning"). In disaster settings, (mental) health experts can highlight specific but critical crisis management aspects. Education and advice on psychosocial principles is also relevant to other partners, such as disaster personnel and emergency workers, primary caregivers (e.g., family physicians), welfare workers, clergy and other community actors (McFarlane, 1984; Powell \& Penick, 1983; Raphael, 1984; Van Loon, 2008).

Including psychosocial support knowledge in decision-making processes enhances the possibility that coordination and meaning making are shaped and conducted in line with the right principles, strengthening and utilizing resilience, and anticipating the deterioration of social support.

\section{Coordination}

Crisis management and post-disaster psychosocial support have in common that both are conducted by actors with different tasks, interests, and responsibilities at different levels in a multidisciplinary inter-organizational network (Bisson et al., 2010; Boin \& 't Hart, 2011; Duickers, Witteveen, Bisson, \& Olff, 2015). The realization of services to affected populations after a disaster requires the involvement of a variety of government, business and civil society actors (Dückers, 2017). These actors will then be enrolled in what we can call a psychosocial support program: "a community intervention that can differ in length (weeks, months, years), scope (variation in themes) and organization (number of partner organizations at different levels)" (Dückers \& Thormar, 2015).

Rescue workers, response team, families, volunteers, community workers, clergy, primary health care-givers, and therapists play a role in providing a supportive context. The PCM-challenge is to pursue cooperation across social groups (including groups of survivors and the bereaved), professional disciplines, organizations, jurisdictions, policy domains, and governmental layers. Without the alignment of activities and interventions and without the deliberate allocation of resources 
Dückers, M.L.A., Yzermans, C.J., Jong, W., Boin, A. Psychosocial crisis management: the unexplored intersection of crisis leadership and psychosocial support. Risk, Hazards \& Crisis in Public Policy: 2017, 8(2), 94-112

(including information), adjusted to different circumstances through time, PCM is bound to fail in its aim to be responsive to needs, problems, risks and stress factors, (a lack of) resilience, and to establish a supportive context reflecting essential principles. Finally, providing information remains a vital element of PCM. News media must be regularly and appropriately briefed, in order to use their potential for disseminating information to the survivors, bereaved families, and the public (Kroon \& Overdijk, 1993; Vasterman, Yzermans, \& Dirkzwager, 2005).

\section{Meaning Making}

Giving meaning to something can have a positive effect on people's resilience and recovery from stressful events (Park, 2016). Benedek and Fullerton (2007) underlined the relevance of the "essential principles" (Hobfoll et al., 2007; see "provide a supportive context" in the previous section), but emphasized something was missing, namely a "vehicle" to bring the principles into practice. In a reaction, Hobfoll stated that the "passageways and obstacles" for the essential principles need to be elaborated (Dückers, 2013). Public leaders can serve as the necessary vehicle. In their meaning-making behavior, crisis managers can provide social acknowledgment and contribute to a sense of connectedness and hope, for example, just by being there and by using well-chosen words.

The meaning-making task is prone to being amplified by (social) media and becomes harder when public discussions are dominated by frustration about unmet expectations, disillusionment and a perceived lack of social support (the second obstacle in Figure 1). After the earthquake at L'Aquila, Italy, in 2009, the public was positive about the initial response and provision of temporary housing by the government, but then unrealistic promises were made. The government promised that permission for evacuees to return to their homes would be granted within a month of the disaster, but the actual repair of homes became a slow, disorganized process that was dependent on funds that were in very short supply (Alexander, 2010). When government involvement becomes a problem in itself, it will become harder for leaders to provide a convincing narrative with explanations and implications. Psychosocially speaking, meaning making requires crisis leaders to consider the potential impact of rituals that are routinely employed in the wake of a disaster. Leaders are expected to play a role in "remembering" the disaster, its impact on people involved, including responders and communities as a whole. Nowadays, societies do not easily allow a disaster to be forgotten. Years after an event there is still a need-political or not—-for commemoration ceremonies and monuments (Boin \& 't Hart, 2011; Eyre, 2007; 't Hart, 1993). While this may be functional in terms of the legitimacy of leaders and institutions, and in terms of connectedness and social support, it could have the opposite impact on survivors and bereaved families who may feel pressured to share their grief in the public arena (Jong, 2013).

\section{Account Giving}

Investigations and inquiries play a role in aiding or inhibiting recovery (Eyre, 2004). In the accountability phase of PCM, social acknowledgment and evaluation of leadership come together. To what degree were psychosocial support principles followed in the response and recovery phase? In practice, PCM can be judged using a broad range of evaluation terms (see "learning"). Crisis managers must render an account of their decisions and handling of response and recovery. This account giving should be broadened to include how PCM was organized. If that is not done, 
Dückers, M.L.A., Yzermans, C.J., Jong, W., Boin, A. Psychosocial crisis management: the unexplored intersection of crisis leadership and psychosocial support. Risk, Hazards \& Crisis in Public Policy: 2017, 8(2), 94-112

or not done properly, the legitimacy of responsible leaders and public institutions may well suffer as a consequence. The effective implementation of psychosocial principles enhances the fate of leaders in the wake of crisis. For instance, 6 years after the Bijlmermeer plane crash disaster in Amsterdam, health complaints escalated, ending in a highly contentious parliamentary investigation procedure, which threatened the ruling coalition (Boin, Van Duin, \& Heyse 2001; Yzermans \& Gersons, 2002).

\section{Learning}

During a crisis, we expect public leaders and crisis managers to take into account feedback that suggests the proposed course of action is not working as envisionedthey can optimize PCM by applying the plan-do-study-act quality improvement model. Learning from a crisis implies that lessons are remembered in the management of the psychosocial impact of a new crisis (this type of plan-do-studyact cycle is shown in Figure 1). Evaluation of PCM can be complicated because of the potential variation in normative viewpoints among stakeholders with respect to needs, problems and capacities of individuals and communities (with in-group and between-group differences), the multi-faceted composition of community programs, and relevant contextual differences (possibly connected to community or societylevel characteristics) that justify another approach.

Moreover, as changes through time matter psychosocially, the evaluation strategy should be responsive to the different challenges crisis leaders have to solve at different time stages. If the response is too passive or too active, the evaluation will be negative (Dückers \& Thormar, 2015). Negative-passive PCM-evaluations are expressed in terms of neglect, disregard, and a lack of insight, involvement, capacity, or opportunity. People can feel abandoned or ignored. The aftermath of the earthquake at L'Aquila (Alexander, 2010) and the Bijlmermeer plane crash disaster in Amsterdam (Boin et al., 2001; Yzermans \& Gersons, 2002) can be seen as examples. Negative-active PCM-evaluations reflect over-attention and wasted resources. Things were done, but probably not the right things. After the Bijlmermeer disaster the mental health interventions made available to many victims were much too short to achieve any lasting result, did not follow an explicit protocol and, in many cases, did not prove to be effective even in the short-term. These and other experiences from the Bijlmermeer plane crash were used to implement an improved program after the Enschede fireworks disaster, almost 10 years later (Yzermans \& Gersons, 2002). This example illustrates how lessons can be implemented in a new cycle of sense making, decision making, etc.

\section{PCM AND HEALTH}

\section{A Two-Way Relation}

Although psychosocial support and crisis management insights stem from different disciplines and traditions, integrating them can reduce foreseeable problems in the response and recovery phases. A key assumption in this line of reasoning, present in the body of knowledge brought together in this article, is that a relation exists between PCM on the one hand, and the well-being, functioning and the health of those affected on the other. This relation works in two directions and this is where the two research disciplines differ in their emphasis. 
Dückers, M.L.A., Yzermans, C.J., Jong, W., Boin, A. Psychosocial crisis management: the unexplored intersection of crisis leadership and psychosocial support. Risk, Hazards \& Crisis in Public Policy: 2017, 8(2), 94-112

Psychosocial support literature is mostly interested in how PCM influences the health of affected people. Norris et al. (2008) describe this type of relation explicitly at community level: "[if] management systems (...) function effectively to protect lives, reduce injuries, minimize damage to public utilities, and connect community members to necessary services, it is reasonable to expect the population to remain well” (p. 133). Psychosocial support literature contains descriptions of interventions and programs, but so far provides little evidence on the health effects of such interventions and programs, nor on the health effects of leadership behavior. Literature on crisis management stresses the implications of disaster health issues for the leader's position. The general well-being of citizens is not an explicit crisis management objective. Authors emphasize the emotional well-being of society primarily with regard to the accountability and responsibility of public leaders ('t Hart, 1993), and the impact on their support from constituencies (Boin \& ' $t$ Hart, 2003; Fairhurst \& Cooren, 2009; Griffin-Padgett \& Allison, 2010; Jong, Dückers, \& Van der Velden, 2016b). In the end, the care for "victims and survivors" tends to be instrumental: a lack of well-being results in declining support from voters and political and institutional turmoil. At the same time, in order to politically survive the crisis, public leaders are more or less obliged to serve the interests of their citizens and to be responsive to their needs. In an ideal situation this shared interest functions as an institutionalized PCM-"safety valve," that is, the self-interest of the leader stimulates to take good care of the interest of disadvantaged citizens. What makes matters complicated is that, post-disaster, public leaders will have to deal with different groups and differing interests within those groups.

\section{Causal Attribution Problem}

The term disaster health effects implies causality between a person's condition and an external source of exposure. Methodologically, verifying a causal relation between the two is vastly complex as actual exposure levels are difficult to ascertain retrospectively while controlling other relevant factors. Causal attribution is a typical problem in disaster health research (Yzermans et al., 2009). Even in case of personal doubts concerning the plausibility of a causal relation, effective PCM requires public leaders to deliver a trustworthy and supportive meaning-making performance.

Whether causality can be verified or not, when it is real in the subjective perceptions of affected individuals and they define it as such, it is real in its consequences, and demands serious attention from crisis managers while shaping the various PCMtasks. This classical Thomas theorem (Thomas \& Thomas, 1928) confronts public leaders with the challenge of finding a balance between social acknowledgment (meaning making) and confirming responsibility or entitlement to compensation (account giving).

\section{CONCLUSION}

Crises are disruptions with a potential psychosocial impact. In this paper, we explored the intersection between crisis leadership and psychosocial support. We identified a lack of integration of the two disciplines in the literature, and presented a PCM-model linking typical crisis leadership challenges to the well-being, functioning, and health of individuals in relation to their social environment. By combining insights from both knowledge domains, the scope of PCM can be better delineated as a distinctive crisis management theme. PCM stretches out over different time stages, from sense making, decision making, coordination, meaning 
Dückers, M.L.A., Yzermans, C.J., Jong, W., Boin, A. Psychosocial crisis management: the unexplored intersection of crisis leadership and psychosocial support. Risk, Hazards \& Crisis in Public Policy: 2017, 8(2), 94-112

making, account giving to learning, confronting public leaders with predictable obstacles in their challenge to integrate the psychosocial support principles into crisis leadership. Clearly, PCM should not disappear from the radar of politicaladministrative elites when the operational phase of the crisis is over. The PCMmodel can assist crisis leaders and researchers to better understand and to evaluate the psychosocial dimension of crisis management. PCM can only be effective if it is integrated into every stage of crisis management.

This paper offers a study model and several angles to formulate and test hypotheses. We encourage more empirical research on the realization of PCM-principles by leaders in different phases of a crisis, and under different circumstances. Particularly interesting topics are: the extent to which PCM-principles are recognized and translated in practice; relevant characteristics and factors explaining the success or failure of PCM (e.g., individual, role, governmental, societal and external sources; Wittkopf, Jones, \& Kegley, 2007); and the nature of the two-way relation between PCM and well-being, and how it can be influenced. Systematic assessments of topics like these have the potential to enhance the forgotten psychosocial dimension of crisis management, and can therefore strengthen crisis management in general. 
Dückers, M.L.A., Yzermans, C.J., Jong, W., Boin, A. Psychosocial crisis management: the unexplored intersection of crisis leadership and psychosocial support. Risk, Hazards \& Crisis in Public Policy: 2017, 8(2), 94-112

\section{REFERENCES}

Alexander, D. 2010. “The L'Aquila Earthquake of 6 April 2009 and Italian Government Policy on Disaster Response." Journal of Natural Resources Policy Research 2 (4): 325-42. . 2012. "Disasters: Lessons Learned?" Journal of Geography \& Natural Disasters 2: $1000 \mathrm{e} 102$.

Amaratunga, C.A. 2006. "In the Path of Disasters: Psychosocial Issues for Preparedness, Response, and Recovery." Prehospital and Disaster Medicine 21 (3): 149-55.

D€uckers et al.: Psychosocial Crisis Management 107 Australian Centre for Posttraumatic Mental Health (ACPMH). 2013. Australian Guidelines for the Treatment of Acute Stress Disorder and Posttraumatic Stress Disorder. Melbourne Victoria: ACPMH.

Back, M.D., A.C.P. K€ufner, and B. Egloff. 2010. "The Emotional Timeline of September 11, 2001." Psychological Science 21 (10): 1417-9.

Basu, M., N. Srivastava, F. Mulyasari, and R. Shaw. 2013. "Making Cities and Local Governments Ready for Disasters: A Critical Overview of Recent Approaches." Risk, Hazards \& Crisis in Public Policy 4 (4): 250-73.

Beerlage, I., and J. Helmerichs. 2011. "Bundeseinheitliche Qualit€atsstandards und Leitlinien in der Psychosozialen Notfallversorgung [Nationwide Quality Standards and Multidisciplinary Guidelines for Psychosocial Crisis Management in Germany]." Trauma und Gewalt 5 (3): 222-35.

Bering, R., A. Elklit, C. Schedlich, and G. Zurek. 2009. "Psychosocial Crisis Management: The Role of Screening, Risk Factors, and Psychopharmacology to Prevent Trauma Related Disorders." Zeitschrift f€ur Psychotraumatologie, Psychotherapiewissenschaft, Psychologische Medizin 7 (3): 61-74.

Benedek, D.M., and C.S. Fullerton. 2007. "Translating Five Essential Elements into Programs and Practice." Psychiatry 70: 345-9.

Bisson, J.I., B. Tavakoly, A.B. Witteveen, D. Ajdukovic, L. Jehel, V.J. Johansen, D. Nordanger et al. 2010. "TENTS Guidelines: Development of Post-Disaster Psychosocial Care Guidelines Through a Delphi Process." British Journal of Psychiatry 196 (1): 69-74.

Boin, A., and F. Bynander. 2015. "Explaining Success and Failure in Crisis Coordination." Geografiska Annaler: Series A, Physical Geography 97 (1): 123-35.

Boin, A., and P. 't Hart. 2003. "Public Leadership in Times of Crisis: Mission Impossible?" Public Administration Review 63 (5): 544-53.

Boin, A., and P. 't Hart. 2011. "Organising for Effective Emergency Management: Lessons From Research." The Australian Journal of Public Administration 69: 357-71.

Boin, A., P. 't Hart, E. Stern, and B. Sundelius. 2016. The Politics of Crisis Management: Public Leadership Under Pressure, 2nd ed. New York: Cambridge University Press.

Boin, R.A., M.J. Van Duin, and L. Heyse. 2001. "Toxic Fear: The Management of Uncertainty in the Wake of the Amsterdam Air Crash." Hazardous Materials 88: 213-34.

Bonanno, G.A., C.R. Brewin, K. Kaniasty, and A.M. La Greca. 2010. "Weighing the Costs of Disaster: Consequences, Risks, and Resilience in Individuals, Families, and Communities." Psychological Science in the Public Interest 11: 1-49.

Bonde, J.P., N. Utzon-Frank, M. Bertelsen, M. Borritz, N.H. Eller, M. Nordentoft, K. Olesen, N.H. Rod, and R. Rugulies. 2016. "Risk of Depressive Disorder Following Disasters and Military Deployment: Systematic Review With Meta-Analysis." The British Journal of Psychiatry 208 (4): 330-36.

Brecher, M. 1993. Crises in World Politics: Theory and Reality. New York: Pergamon. Brewin, C.R., B. Andrews, and J.D. Valentine. 2000. "Meta-Analysis of Risk Factors for Post-Traumatic Stress Disorder in Trauma-Exposed Adults." Journal of Consulting and Clinical Psychology 68: 748-66.

Buckle, P., J. Brown, and M. Dickinson. 1998. "Supporting the Entire Person: A Comprehensive Approach to Supporting People Affected by Emergencies and Disasters." Australian Journal of Emergency Management 13 (2): 35-8.

Burkle, F.M. 1996. "Acute-Phase Mental Health Consequences of Disasters: Implications for Triage and Emergency Medical Services." Annals of Emergency Medicine 28 (2): 119-28.

Clark, D.W., and P. Volmann. 2005. "Enhancing the Crisis Management Briefing." International Journal of Emergency Mental Health 7 (2): 133-40. 
Dückers, M.L.A., Yzermans, C.J., Jong, W., Boin, A. Psychosocial crisis management: the unexplored intersection of crisis leadership and psychosocial support. Risk, Hazards \& Crisis in Public Policy: 2017, 8(2), 94-112

Comfort, L.K., M.D. Siciliano, and A. Okada. 2011. "Resilience, Entropy, and Efficiency in Crisis Management: The January 12, 2010, Haiti Earthquake." Risk, Hazards \& Crisis in Public Policy 2 (3): 1-25.

Dückers, M., M. Rooze, and D. Alexander. 2014. "Towards Resilient Organization of Recovery and Care after Disaster." In Drowning: Prevention, Rescue, Treatment, ed. J.J.L.M Bierens. Berlin Heidelberg: Springer-Verlag, 1033-8.

Dückers, M.L.A. 2017. "A Multi-Layered Psychosocial Resilience Framework and Its Implications for Community-Focused Crisis Management." Journal of Contingencies and Crisis Management Articlein-press. 2013. "Five Essential Principles of Post-Disaster Psychosocial Care: Looking Back and Forward With Stevan Hobfoll." European Journal of Psychotraumatology 4: 21914.

D€uckers, M.L.A., A.B. Witteveen, J.I. Bisson, and M. Olff. 2015. "The Association Between Disaster Vulnerability and Post-Disaster Psychosocial Service Delivery Across Europe." Administration and Policy in Mental Health and Mental Health Services Research E-pub ahead of print.

D€uckers, M.L.A., and S.B. Thormar. 2015. "Post-Disaster Psychosocial Support and Quality Improvement: A Conceptual Framework for Understanding and Improving the Quality of Psychosocial Support Programs." Nursing \& Health Sciences 17: 159-65.

Dudley-Grant, G.R., G.I. Mendez, and J. Zinn. 2000. "Strategies for Anticipating and Preventing Psychological Trauma of Hurricanes Through Community Education." Professional Psychology: Research and Practice 31 (4): 387-92.

Everly, G.S. 2000. "Crisis Management Briefings (CMB): Large Group Crisis Intervention in Response to Terrorism, Disasters, and Violence." International Journal of Emergency Mental Health 2 (1): 53-7.

Eyre, A. 2004. "Psychosocial Aspects of Recovery: Practical Implications for Disaster Managers." Australian Journal of Emergency Management 19 (4): 23-7.

- 2007. "Remembering: Community Commemoration After Disaster." In Handbook of Disaster Research, ed. H. Rodr_iguez, E.L. Quarantelli, and R.R. Dynes. New York: Springer, 441-55.

Fairhurst, G.T., and F. Cooren. 2009. "Leadership as the Hybrid Production of Presence(s)." Leadership 5 (4): 469-90.

Galea, S., A. Nandi, and D. Vlahov. 2005. "The Epidemiology of Post-Traumatic Stress Disorder After Disasters.” Epidemiologic Reviews 27 (1): 78-91.

Greenberg, N., G.J. Rubin, and S. Wessely. 2009. "The Psychological Consequences of the London Bombings." In Mental Health and Disasters, ed. Y. Neria, S. Galea, and F.H. Norris. New York, NY, US: Cambridge University Press, 538-57.

Griffin-Padgett, D.R., and D. Allison. 2010. "Making a Case for Restorative Rhetoric: Mayor Rudolph Giuliani \& Mayor Ray Nagin's Response to Disaster." Communication Monographs 77 (3): 376-92.

Hammond, J., and J. Brooks. 2002. "The World Trade Center Attack: Helping the Helpers: The Role of Critical Incident Stress Management." Critical Care 5 (6): 315-7.

Hannig, C., and V. Harks. 2009. "Kultursensitive Psychosoziale Notfallversorgung in Deutschland: Hintergr€unde, Grundlagen und Ausbildungsans€atze [Culture-Sensitive Psychosocial Crisis Management in Germany: Backgrounds, Basics and Approaches to Trainings]." Zeitschrift f€ur Psychotraumatologie, Psychotherapiewissenschaft, Psychologische Medizin 7 (4): 11-23.

Heller, D.S. 2010. "Evacuation Planning in the Aftermath of Katrina: Lessons Learned." Risk, Hazards \& Crisis in Public Policy 1 (2): 131-74.

Herbert, R., J. Moline, G. Skloot, K. Metzger, S. Baron, B. Luft, S. Markowitz et al. 2006. "The World Trade Center Disaster and the Health of Workers: Five-Year Assessment of a Unique Medical Screening Program." Environmental Health Perspectives 114: 1853-8. Hobfoll, S.E. 1998. Stress, Culture, and Community: The Psychology and Philosophy of Stress. New York: Plenum.

Hobfoll, S.E., P. Watson, C.C. Bell, R.A. Bryant, M.J. Brymer, M.J. Friedman, M. Friedman et al. 2007. "Five Essential Elements of Immediate and Mid-Term Mass Trauma Intervention: Empirical Evidence." Psychiatry 70 (4): 283-315. 
Dückers, M.L.A., Yzermans, C.J., Jong, W., Boin, A. Psychosocial crisis management: the unexplored intersection of crisis leadership and psychosocial support. Risk, Hazards \& Crisis in Public Policy: 2017, 8(2), 94-112

Jong, W. 2013. Ingrijpende Gebeurtenissen. Bestuurlijke Ervaringen bij Crises Met Lokale Impact [Shocking Events. Experiences of Public Leaders in Crises With Local Impact]. Nederlands Genootschap van Burgemeesters: Den Haag.

Jong, W. and M.L.A. D€uckers. 2016. "Self-Correcting Mechanisms and Echo-Effects in Social Media: An Analysis of the 'Gunman in the Newsroom'." Computers in Human Behavior 59: 334-41.

D€uckers et al.: Psychosocial Crisis Management 109 Jong, W., M.LA. D€uckers, and P.G. Van der Velden. 2016a. "Crisis Leadership by Mayors: A Qualitative Content Analysis of Newspapers and Social Media on the MH17 Disaster." Journal of Contingencies and Crisis Management 24 (4): 286-95.

- 2016b. "Leadership of Mayors and Governors During Crises: A Systematic Review on Tasks and Effectiveness." Journal of Contingencies and Crisis Management 24 (1): 4658.

Juen, B., R. Warger, S. Nindl, H. Siller, M.J. Lindenthal, E. Huttne, D. Ajdukovic et al. 2015. The Comprehensive Guideline on Mental Health and Psychosocial Support in Disaster Settings. Innsbruck: OPSIC.

Kaniasty, K., and F.H. Norris. 2004. "Social Support in the Aftermath of Disasters, Catastrophes, and Acts of Terrorism: Altruistic, Overwhelmed, Uncertain, Antagonistic, and Patriotic Communities." In Bioterrorism: Psychological and Public Health Interventions, ed. R. Ursano, A. Norwood, and C. Fullerton. Cambridge: Cambridge University Press, 20029.

Kaniasty, K., F.H. Norris, and S.A. Murrell. 1990. "Perceived and Received Social Support Following Natural Disaster." Journal of Applied Social Psychology 20 (2): 85-114.

Kapucu, N., C.V. Hawkins, and F.I. Rivera. 2013. "Disaster Preparedness and Resilience for Rural Communities." Risk, Hazards \& Crisis in Public Policy 4 (4): 215-33.

Korteweg, H.A., I. Van Bokhoven, C.J. Yzermans, and L. Grievink. 2010. "Rapid Health and Needs Assessments: A Systematic Review." BMC Public Health 10: 295.

Kroon, M.B.R., and I.E. Overdijk. 1993. "Psychosocial Care and Shelter Following the Bijlmermeer Air Disaster." Crisis 14 (3): 117-25.

Maercker, A., and J. M€uller. 2004. "Social Acknowledgment as a Victim or Survivor: A Scale to Measure a Recovery Factor of PTSD." Journal of Traumatic Stress 17 (4): 345-51.

McFarlane, A.C. 1984. "The Ash Wednesday Bushfires in South Australia: Implications for Planning for Future Post-Disaster Services." Medical Journal of Australia 141 (5): 286-91.

Mitchell, J.T., and G.S. Everly. 2006. "Critical Incident Stress Management in Terrorist Events and Disasters." In Psychological Effects of Catastrophic Disasters: Group Approaches to Treatment, ed. L.A. Schein, H.I.

Spitz, G.M. Burlingame, and P.R. Muskin. Binghamton, New York: Haworth Press, 425-80. Moline, J., R. Herbert, and N. Nguyen. 2006. "Health Consequences of the September 11 World Trade Center Attacks: A Review." Cancer Investigation 24 (3): 294-301.

Norris, F.H., M.J. Friedman, P.J. Watson, C.M. Byrne, E. Diaz, and K. Kaniasty. 2002. "60,000 Disaster Victims Speak: Part I. An Empirical Review of the Empirical Literature, 1981-2001." Psychiatry 65 (3): 207-39.

Norris, F.H., J.L. Hamblen, P.J. Watson, J.I. Ruzek, L.E. Gibson, B.J. Pfefferbaum, J.L. Price et al. 2006. "Toward Understanding and Creating Systems of Postdisaster Care: A Case Study of New York's Response to the World Trade Center Disaster." In Interventions Following Mass Violence and Disasters: Strategies for Mental Health Practices, ed. E.C. Ritchie, P.J. Watson, M.J. Friedman, and J. Matthew. New York: Guilford Press, 343-64. Norris, F.H., S.P. Stevens, B. Pfefferbaum, K.F. Wyche, and R.L. Pfefferbaum. 2008.

"Community Resilience as a Metaphor, Theory, Set of Capacities, and Strategy for Disaster Readiness." American Journal of Community Psychology 41 (1-2): 127-50.

Omer, H., and N. Alon. 1994. "The Continuity Principle: A Unified Approach to Disaster and Trauma." American Journal of Community Psychology 22 (2): 273-87.

Ozer, E.J., S.R. Best, T.L. Lipsey, and D.S. Weiss. 2003. "Predictors of Posttraumatic Stress Disorder and Symptoms in Adults: A Meta-Analysis." Psychological Bulletin 129 (1): 52-73.

Park, C.L. 2016. "Meaning Making in the Context of Disasters." Journal of Clinical Psychology 72 (12): 1234-46. 
Dückers, M.L.A., Yzermans, C.J., Jong, W., Boin, A. Psychosocial crisis management: the unexplored intersection of crisis leadership and psychosocial support. Risk, Hazards \& Crisis in Public Policy: 2017, 8(2), 94-112

Powell, B.J., and E.C. Penick. 1983. "Psychological Distress Following a Natural Disaster: A One-Year Follow-Up of 98 Flood Victims." Journal of Community Psychology 11 (3): 26976.

Rao, K. 2006. "Psychosocial Support in Disaster-affected Communities." International Review of Psychiatry 18 (6): 501-505.

Raphael, B. 1984. "Psychiatric Consultancy in Major Disaster." Australian and New Zealand Journal of Psychiatry 18 (4): 303-6. . 1986. When Disaster Strikes: How Individuals and Communities Cope With Catastrophe. New York: Basic Books.

Reifels, L., L. Pietrantoni, G. Prati, Y. Kim, D.G. Kilpatrick, G. Dyb, J. Halpern et al. 2013. "Lessons Learned About Psychosocial Responses to Disaster and Mass Trauma: An International Perspective." European Journal of Psychotraumatology 4: 22897.

Rosenthal, U., A. Boin, and L.K. Comfort. 2001. Managing Crises: Threats, Dilemmas, Opportunities. Springfield, IL: Charles C Thomas Publisher.

Rosenthal, U., M.T. Charles, and P. 't Hart. (ed.) 1989. Coping With Crises: The

Management of Disasters, Riots and Terrorism. Springfield, IL: Charles Thomas.

Salama, P., P. Spiegel, L. Talley, and R. Waldman. 2004. "Lessons Learned From Complex Emergencies Uver Past Decade.” The Lancet 364 (9447): 1801-13.

Shrivastava, P., I.I. Mitroff, D. Miller, and A. Miglani. 1988. "Understanding Industrial Crises." Journal of Management Studies 25 (4): 285-304.

Smith, D., and D. Elliott. 2007. "Exploring the Barriers to Learning From Crisis: Organizational Learning and Crisis." Management Learning 38 (5): 519-38.

Stern, E.K. 1997. "Crisis and Learning: A Balance Sheet." Journal of Contingencies and Crisis Management 5 (2): 69-86.

Stern, E., and B. Sundelius. 2002. "Crisis Management Europe: An Integrated Regional Research and Training Program." International Studies Perspectives 3 (1): 71-88.

Te Brake, H., and M. D€uckers. 2013. "Early Psychosocial Interventions After Disasters, Terrorism and Other Shocking Events: Is There a Gap Between Norms and Practice in Europe?" European Journal of Psychotraumatology 4: 19093.

Thomas, W.I., and D.S. Thomas. 1928. The Child in America: Behavior Problems and Programs. New York: Alfred A. Knopf.

't Hart, P. 1993. "Symbols, Rituals and Power: The Lost Dimensions of Crisis Management." Journal of Contingencies and Crisis Management 1 (1): 36-50.

Uhle, R., and W. Haubner. 2005. "Schulische Notfallsituationen: Psychologisches Krisenmanagement im System Schule [Emergency Situations in Schools: Psychological Crisis Management in the Educational System." Verhaltenstherapie \& Psychosoziale Praxis 37 (2): 275-92.

Van der Velden, P.G., P. Van Loon, R.J. Kleber, S. Uhlenbroek, and J. Smit. 2009. "Naar een Brede Visie op Psychosociale Interventies na Schokkende Gebeurtenissen: Suggesties voor een Herziening van Richtlijnen [Toward a Broad Vision on Psychosocial Interventions After Shocking Events: Suggestions for Guideline Revision]." De Psycholoog 43: $568-757$.

Van Loon, P. 2008. "Psychosociaal Crisismanagement na Calamiteiten: Casussen en Interventies [Psychosocial Crisis Management After Calamities: Cases and Interventions]." Psychologie \& Gezondheid 36 (3): 111-6.

Vasterman, P., C.J. Yzermans, and A.J. Dirkzwager. 2005. "The Role of the Media and Media Hypes in the Aftermath of Disasters." Epidemiologic Reviews 27 (1): 107-14.

Vernberg, E.M. 2002. "Intervention Approaches Following Disasters." In Helping Children Cope With Disasters and Terrorism, ed. A.M. La Greca, W.K. Silverman, E.M. Vernberg, and M.C. Roberts. Washington, DC: American Psychological Association, 55-72.

Vymetal, S. 2006. "Central System of Psychosocial Support to the Czech Victims Affected by the Tsunami in Southeast Asia." Prehospital and Disaster Medicine 21 (S1): S27-31.

Weaver, J.D. 1995. Disasters: Mental Health Interventions. Sarasota, FL: Professional Resource Press.

Weick, K.E. 1988. "Enacted Sensemaking in Crisis Situations." Journal of Management Studies 25 (4): 305-17.

Wittkopf, E.R., C.M. Jones, and C.W. Kegley. 2007. American Foreign Policy: Pattern and Process, 7th ed. Belmont: Thomson Learning. 
Dückers, M.L.A., Yzermans, C.J., Jong, W., Boin, A. Psychosocial crisis management: the unexplored intersection of crisis leadership and psychosocial support. Risk, Hazards \& Crisis in Public Policy: 2017, 8(2), 94-112

World Health Organization. 2013. "Guidelines for the Management of Conditions Specifically Related to Stress." Geneva: WHO.

D€uckers et al.: Psychosocial Crisis Management 111

Yzermans, J., C. Baliatsas, S. Van Dulmen, and I. Van Kamp. 2016. "Assessing Non-specific Symptoms in Epidemiological Studies: Development and Validation of the Symptoms and Perceptions (SaP) Questionnaire." International Journal of Hygiene and Environmental Health 219 (1): 53-65.

Yzermans, C.J., and B.P.R. Gersons. 2002. "The Chaotic Aftermath of an Airplane Crash in Amsterdam: A Second Disaster." In Toxic Turmoil; Psychological and Societal Consequences of Ecological Disasters, ed. J.M. Havenaar, J.G. Cwikel, and E.J. Bromet. New York: Kluwer Academic/Plenum Publishers, 85-100.

Yzermans, C.J., B. Van Der Berg, and A.J.E. Dirkzwager. 2009. "Physical Health Problems After Disasters." In Mental Health and Disasters, ed. Y. Neria, S. Galea, and F.H. Norris. New York: Cambridge University Press, 67-93.

\section{FigURE AND TABLES}

Figure 1: Psychosocial Crisis Management: Crisis Leadership Guided by Psychosocial Principles.

Note. Crisis leadership challenges and psychosocial support principles are shown here in different rings, centered around the well-being, functioning, and health of citizens exposed to potentially traumatic events. General leadership challenges, originating from crisis management studies, are linked to post-disaster psychosocial support principles identified in the literature. While psychosocial support principles are particularly relevant to professionals and trained volunteers (e.g., rescue workers, family physicians, mental health professionals, social workers, and clergy), from a PCM-perspective they also provide meaningful guidance to public leaders with a responsibility for the well-being, functioning, and health of citizens at national or local community level. The crisis leadership tasks and the psychosocial support principles are structured anti-clockwise along the stages in the plan-do-study-act cycle. PCM encompasses different time phases in which public leaders must overcome several obstacles while shaping sense making, decision making, coordination, meaning making, account giving, and learning tasks. 
Dückers, M.L.A., Yzermans, C.J., Jong, W., Boin, A. Psychosocial crisis management: the unexplored intersection of crisis leadership and psychosocial support. Risk, Hazards \& Crisis in Public Policy: 2017, 8(2), 94-112

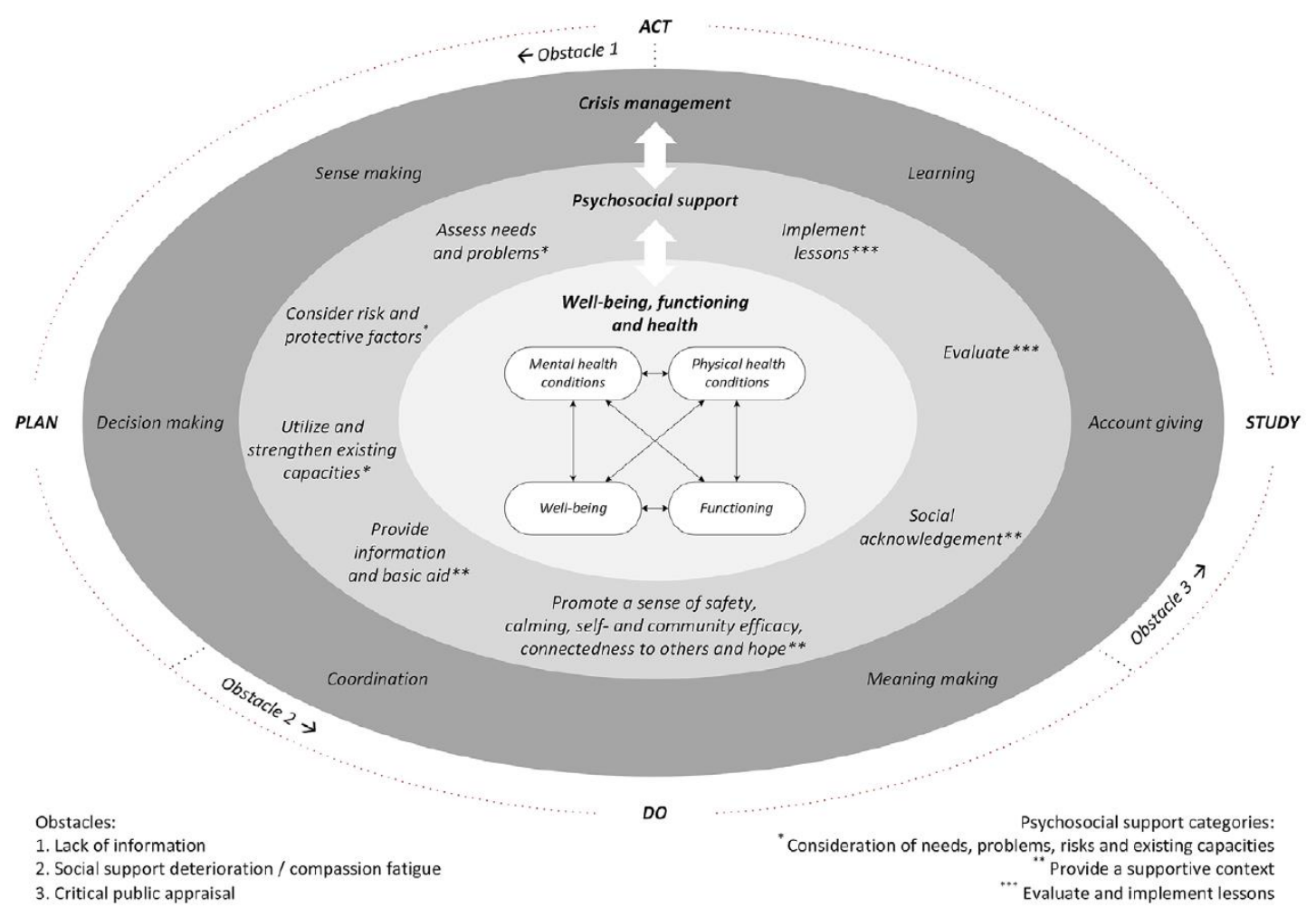

